\title{
Length at first maturity of cobia Rachycentron canadum (Linnaeus, 1766) from north-west coast of India
}

\author{
M. K. SAJEEVAN AND B. MADHUSOODANA KURUP* \\ Fishery Survey of India, Botawala Chambers, Mumbai - 400 001, Maharashtra, India \\ ${ }^{*}$ Kerala University of Fisheries and Ocean Studies, Panangad, Kochi - 682 506, Kerala, India \\ e-mail: sajeevanfsi@gmail.com
}

\begin{abstract}
The length at first maturity of cobia Rachycentron canadum (Linnaeus, 1766) was estimated from 292 specimens collected during exploratory surveys along the north-west coast of India and from fish landing centres in Mumbai, Maharashtra. Length and age at first maturity of male and female were estimated as 63 and $70 \mathrm{~cm}$ and 1.5 and 1.75 years respectively.
\end{abstract}

Keywords: Age at maturity, Cobia, India, Length at maturity

Reproductive aspects such as size at first maturity, sex ratio, spawning season and recruitment are of great value in fishery prediction and management of fishery resources (Bal and Rao, 1984). Detailed knowledge on reproductive biology of a species will provide vital information on its life history traits, which will be of use in management and conservation of the resource in the wild, as well as in evolving aquaculture and husbandry practices.

The cobia Rachycentron canadum (Linnaeus, 1766) is a constituent of marine fish landings in many places along the Indian coast and of late, has acquired considerable aquaculture significance. Sajeevan and Kurup (2013; 2014 a, b) provided information on feeding intensity, systematics, distribution and abundance of cobia inhabiting Indian waters. However, there is not much information on its reproductive biology from Indian waters. Rajan et al. (1968), Somvanshi et al. (2000), Pillai et al. (2009) and Ganga et al. (2012) provided some preliminary information on reproductive biology of cobia from Indian waters. Richards (1967), Smith (1995) and Lotz et al. (1996) have reported on the size at maturity of cobia from other parts of the world. The present study was undertaken to estimate the length at first maturity of cobia from north-west coast of India.

Samples collected during exploratory surveys of the vessel M. V. Matsya Nireekshani of the Mumbai Base of Fishery Survey of India and from the local landing centers at Mumbai were used for the present study. A total of 292 specimens (162 male and 130 female) collected during the period from January 2008 to December 2009 were analysed for the study. Total length of fish was measured to the nearest $1 \mathrm{~cm}$ and total weight to the nearest $1 \mathrm{~g}$. Sex of individual specimen was determined by observing the gonads after dissecting the specimens, whereas the sex of juveniles were identified by microscopic examination of gonads. Stages of maturity of gonads were determined based on morphological appearance. Five stages were identified through macroscopic observations following Qasim (1973).

Fishes belonging to maturity stage III onwards were considered as mature fish and used for calculating the size at first maturity. Specimens with spent/recovering ovary were not included in the calculations as that often leads to biased inference.

Fishes were grouped into different length class of $10 \mathrm{~cm}$ class intervals, following Arendt et al. (2001). Percentage of mature and immature fish in different size groups was analysed. The length at which $50 \%$ of fish were mature was considered as length at first maturity (Lm) for both sexes (Hodgkiss and Man, 1978). Lm value was substituted in von Bertlanfy growth equation derived for this species to estimate the age at maturity. Growth parameters were taken as $\mathrm{L}_{\infty}=194.25 \mathrm{~cm} ; \mathrm{K}=0.24$ per year and $\mathrm{t}_{0}=-0$. 1567 years (Sajeevan, 2011).

The percentage occurrence of mature individuals was plotted against different size groups in male and female (Fig. 1). All the fishes below $40 \mathrm{~cm}$ were found to be immature. About $18.45 \%$ males and $13.04 \%$ females in the length group $40-50 \mathrm{~cm}$ were observed as mature. More than $50 \%$ of both male and female were found mature in the size group $60-70 \mathrm{~cm}$ total length. The length at first maturity of male was estimated at $63 \mathrm{~cm}$, while in the case of female, it was $70 \mathrm{~cm}$. By fitting these lengths to the VBGF equation, age at first maturity of male and female was estimated as 1.5 and 1.7 years respectively. 


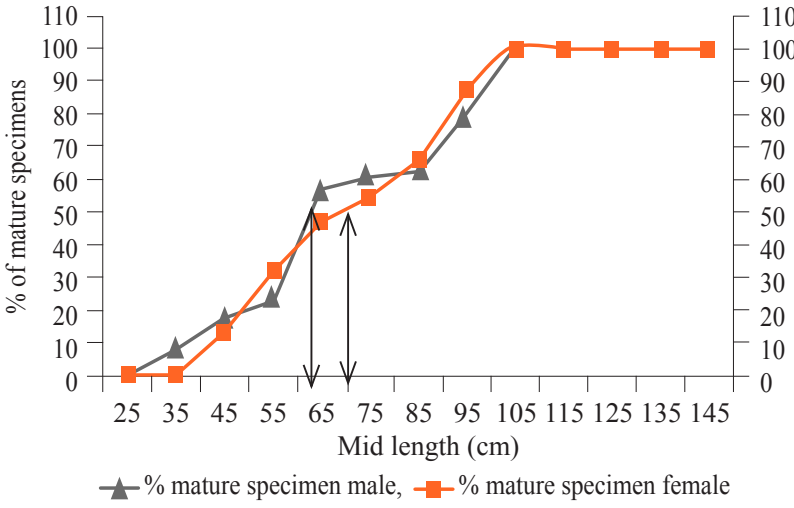

Fig. 1. Length at first maturity of male and female Rachycentron canadum

In the present study, 13 mature specimens were recorded in the length group of $40-50 \mathrm{~cm}$, indicating that the onset of maturity in cobia occurs early, at 40-50 cm total length in tropical waters. Rajan et al. (1968) reported that $42.6 \mathrm{~cm}$ long mature female specimen from Chilka Lake in Odisha. Richards (1967) estimated the size at early maturity of male cobia from Chesapeake Bay, USA at $51.8 \mathrm{~cm}$.

Sizes at first maturity of cobia reported by different authors from various localities (Table 1) range from $42.6 \mathrm{~cm}$ in Chilka Lake, India (Rajan et al., 1968), to $84.5 \mathrm{~cm}$ in Gulf of Mexico (Williams, 2001). However, et al. (2011) reported that cobia mature at the age of 1-2 years. Kaiser and Holt (2004) reported that male cobia can reach sexual maturity at the age of one and female mature at the age of two. The results of the present study are in concurrence with these findings. However, Richards (1967) estimated the age at maturity of cobia inhabiting Chesapeake Bay as 2 years and 3 years for male and female respectively.

Size and age at first maturity depends on the nature of the environment in which the population of the species inhabits (Moyle and Cech, 2000). Hence geographical difference, differences in physicochemical parameters of the habitat as well as differences in food availability can be considered as the major reasons for such variation.

\section{Acknowledgements}

The authors are grateful to Prof. (Dr.) A. Ramachandran, Director, School of Industrial Fisheries for granting permission and providing necessary facilities for the successful conduct of the study. The authors also thank Dr. K. Vijayakumaran, former Director General, Fishery Survey of India, Mumbai and Dr. V. S. Somvanshi, former Director General, Fishery Survey of India, Mumbai for the facilities provided. The authors also thank the officers and crew of M. V. Matsya Nireekshani.

Table 1. Length at first maturity of Rachycentron canadum reported by various authors from different localities

\begin{tabular}{|c|c|c|c|}
\hline \multirow{2}{*}{ Author/s } & \multirow{2}{*}{ Area of study } & \multicolumn{2}{|c|}{ Length at first maturity in $\mathrm{cm}(\mathrm{TL} / \mathrm{FL})^{*}$} \\
\hline & & Female & Male \\
\hline Richards (1967) & Chesapeake Bay-East, USA; Chesapeake Bay- West, USA & $69.6(\mathrm{FL})$ & $51.8(\mathrm{FL})$ \\
\hline Rajan et al. (1968) & Chilka Lake, India & 42.6(TL) & NA \\
\hline Smith (1995) & North Carolina, USA & $70(\mathrm{FL})$ & - \\
\hline Lotz et al. (1996) & North Central Gulf of Mexico & $83.4(\mathrm{FL})$ & $64.0(\mathrm{FL})$ \\
\hline Williams (2001) & Gulf of Mexico & 84.5 & 64 \\
\hline Kaiser and Holt (2005) & Texas, USA & $83.4(\mathrm{FL})$ & $64.0(\mathrm{FL})$ \\
\hline Tonya et al. (2010) & North-eastern Australia & $78.4(\mathrm{FL})$ & $77(\mathrm{FL})$ \\
\hline Present study & North-west coast of India & 70 (TL) & 63 (TL) \\
\hline
\end{tabular}

*TL: Total length, FL: Fork length

all the studies are concurrent in reporting that size at maturity of male and female differs from each other.

The present study indicates that male cobia matures at smaller length than female, as reported by other workers (Richards, 1967; Lotz et al., 1996; Williams, 2001; Kaiser and Holt, 2005, Tonya et al., 2010). Faster growth rate recorded for female cobia (Sajeevan, 2011) can be attributed as one of the reasons for this difference in size at first maturity of the two sexes.

Age at first maturity estimated for male and female cobia was 1.5 and 1.75 years respectively. Gopakumar

\section{References}

Arendt, M. D., Olney, J. E. and Lucy, J. A. 2001. Stomach content analysis of cobia, Rachycentron canadum from lower Chesapeake Bay. Fish. Bull., 99(4): 665-670.

Bal, D. V. and Rao, K. V. 1984. Marine fisheries. Tata McGraw-Hill Publishing Company, New Delhi, 470 pp.

Ganga, U., Pillai, N. G. K., Akhilesh, K. V., Rajoolshanis, C. P., Beni, N., Hashim, M. and Prakashan, D. 2012. Population dynamics of cobia, Rachycentron canadum (Linnaeus, 1766) off Cochin coast, south-eastern Arabian Sea. Indian J. Fish., 59(3): 15-20. 
Gopakumar, G., Abdulnazar, A. K., Tamilmani, G., Sakthivel, M., Kalidas, C., Ramamoorthy, N., Palanichamy, S., Ashokmaharshi, V., Rao, K. S. and Syda Rao, G. 2011. Broodstock development and controlled breeding of cobia Rachycentron canadum (Linnaeus, 1766) from Indian seas. Indian J. Fish., 58(4): 27-32.

Hodgkiss, I. J. and Man, H. S. H. 1978. Reproductive biology of Sarotherodon mossambicus (Cichlidae) in Plover Cove Reservoir, Hong Kong. Env. Biol. Fish., 3(3): 287-292.

Kaiser, J. B. and Holt, G. J. 2004. Cobia: A new species for aquaculture in the U. S. World Aquac. Mag., 35(2): 12-14.

Kaiser, J. B. and Holt, G. J. 2005. Species profile of cobia. SRAC Pub., 7202: 1-6.

Lotz, J. M., Overstreet, R. M. and Franks, J. S. 1996. Gonadal maturation in the cobia Rachycentron canadum, from the north central Gulf of Mexico. Gulf Res. Rep., 9: 147-159.

Moyle, P. M. and Cech, J. J. Jr. 2000. Fishes: An introduction to ichthyology. Prentice-Hall Inc., NJ, 611 pp.

Pillai, N. G. K., Ganga, U. and Akhilesh, K. V. 2009. Some aspects of fishery and biology of cobia, Rachycentron canadum (Linnaeus, 1766) in the Indian Waters. In: Vivekanandan, E., Najmudeen, T. M., Naomi, T. S., Gopalakrishnan, A., Jayachandran, K. V. and Harikrishnan, M. (Eds.), Book of Abstracts, Marine ecosystem - Challenges and opportunities, 9-12 February 2009, Cochin, p. 47-48.

Qasim, S. Z. 1973. An appraisal of the studies on maturation and spawning in marine teleosts from the Indian waters. Indian J. Fish., 20: 166-181.

Rajan, S., Patnaink, S. and Basu, N. C. 1968. New records of fishes from the Chilka Lake. J. Zool. Soc. India, 20(1/2): 80-93.

Richards, C. E. 1967. Age, growth and fecundity of the cobia, Rachycentron canadum from Chesapeake Bay and adjacent mid-Atlantic waters. Trans. Am. Fish. Soc., 96(3): 343-350.
Sajeevan, M. K. 2011. Systematics, life history traits, abundance and stock assessment of cobia Rachycentron canadum (Linnaeus, 1766) occurring in Indian waters with special reference to the north-west coast of India. Ph. D. Thesis, Cochin University of Science and Technology, Kochi, $271 \mathrm{pp}$.

Sajeevan, M. K. and Kurup, B. M. 2013. Evaluation of feeding indices of cobia Rachycentron canadum (L. 1766) from north-west coast of India. J. Mar. Biol. Ass. India, 55(2): 16-21.

Sajeevan, M. K. and Kurup, B. M. 2014a. Osteological features of cobia, Rachycentron canadum (Linnaeus, 1766). J. Ocean Sci. Found., 11: 40-49.

Sajeevan, M. K. and Kurup, B. M. 2014b. Distribution and abundance of cobia Rachycentron canadum (Linnaeus, 1766) occurring in Indian waters. Asian Fish. Sci., 27: $274-285$.

Smith, J. W. 1995. Life history of cobia, Rachycentron canadum (Osteichthyes: Rachycentridae), in North Carolina waters. Brimleyana, 23: 1-23.

Somvanshi, V. S., Vargese, S., Gulati, D. K. and Bhargava, A. K. 2000. Some biological aspects of kingfish Rachycentron canadum (Linnaeus, 1766) from the north-west Indian EEZ. Occational Paper, Fishery Survey of India, FSI, Mumbai, $36 \mathrm{pp}$.

Tonya, V. D., Griffiths, S. P. and Fry, G. C. 2010. Reproductive biology of the commercially and recreationally important cobia Rachycentron canadum in north-eastern Australia. Fish. Sci., 76(1): 33-43.

Williams, E. H. 2001. Assessment of cobia, Rachycentron canadum, in the waters of the U.S. Gulf of Mexico. NOAA Technical Memorandum NMFS-SEFSC-469, 54 pp. 